\title{
Medievalista
}

Online

$29 \mid 2021$

Número 29

\section{Ascenso y caída de las bestias: evolución de la alegoría animal en la Edad Media}

Rise and fall of beasts: evolution of animal allegory in the Middle Ages

\section{Claudia Inés Raposo}

\section{(2) OpenEdition}

12 Journals

\section{Edição electrónica}

URL: https://journals.openedition.org/medievalista/3887

DOI: 10.4000/medievalista.3887

ISSN: 1646-740X

\section{Editora}

Instituto de Estudos Medievais - FCSH-UNL

\section{Edição impressa}

Paginação: 149-181

\section{Refêrencia eletrónica}

Claudia Inés Raposo, «Ascenso y caída de las bestias: evolución de la alegoría animal en la Edad Media », Medievalista [Online], 29 | 2021, posto online no dia 01 janeiro 2021, consultado o 11 junho 2021. URL: http://journals.openedition.org/medievalista/3887 ; DOI: https://doi.org/10.4000/ medievalista.3887

\section{Este documento foi criado de forma automática no dia 11 junio 2021.}

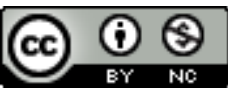

Mediavalista está licenciado com uma Licença Creative Commons - Atribuição-NãoComercial 4.0 Internacional. 


\title{
Ascenso y caída de las bestias: evolución de la alegoría animal en la Edad Media
}

Rise and fall of beasts: evolution of animal allegory in the Middle Ages

\author{
Claudia Inés Raposo
}

\section{NOTA DO EDITOR}

Data recepção do artigo / Received for publication: 31 de Dezembro de 2019

Data aceitação do artigo / Accepted in revised form: 23 de Setembro de 2020

\section{Introducción}

2 En Alejandría, en los primeros siglos de la era cristiana, los Padres griegos se encontraron enfrentados a un doble desafío: por un lado, conciliar el legado cultural pagano en el que estaban inmersos con la tradición cristiana a la que debían responder, sorteando dialécticamente la condena de San Pablo a la sabiduría de este mundo ${ }^{1}$. Por otro, expandir la nueva religión, para lo cual necesitaban herramientas que permitieran transmitir las enseñanzas de las Sagradas Escrituras. Un ejemplo de síntesis pagano-cristiana al servicio de la catequesis y de la conversión fue la apropiación, por parte de la Escuela de Alejandría, de la interpretación alegórica. Los antiguos griegos la aplicaron a los grandes mitos religiosos y poéticos, especialmente a la obra de Homero, "para develar en los textos de ayer la verdad del presente"2. Los exégetas cristianos adoptaron la alegoría para multiplicar y proyectar los sentidos de El Texto por excelencia, la Biblia; el ejemplo más acabado es, quizás, Orígenes y su escuela. Esta forma de interpretación, junto con la figural se extendió a la Edad Media. En su desarrollo histórico, el campo de la alegoría fue ampliándose y se aplicó también a otros textos no religiosos. Este trabajo intenta discutir, precisamente, su adaptación a aquellos escritos que versaban sobre materia animal, su apogeo y decadencia, y las 
relaciones de estos procesos con la evolución de las ideas y el cambio de las mentalidades en el tardomedioevo.

literal (littera) pero que lo interpreta como signo de un sentido profundo (sententia) que es preciso desentrañar. Frecuentemente confundida con la figura o tipo, o utilizada como sinónimo ${ }^{3}$, se distingue de esta por su elemental ahistoricidad. Según Lausberg, su fin es la interpretación del texto, mientras que el de la figura es la interpretación de hechos históricos, reales o considerados como tales: la alegoría es una semántica de las palabras, independiente de cualquier anclaje histórico, mientras que la interpretación figural o tipología es una semántica de las realidades ${ }^{4}$. Luego, la aplicación de la alegoría trascendió a los textos y se extendió también al mundo natural inmediato: astros, animales, plantas y piedras sumaron a su inmediata realidad sensible un significado oculto, que era necesario develar ${ }^{5}$. Es fue el punto de partida de la aparición del Fisiólogo alejandrino, y de las traducciones y bestiarios a los que dio origen.

Los Bestiarios o libros de bestias son colecciones, frecuentemente ilustradas, de descripciones de animales, las cuales son interpretadas como ejemplos o lecciones morales o espirituales. Estrictamente hablando, no trataban sólo de animales, sino que compilaban también información acerca de árboles y piedras. El primero de ellos, que dio origen a todos los demás, fue el Fisiólogo, El Naturalista, identificado como nombre de autor. Escrito originalmente en griego, fue traducido al etíope, siríaco, copto, armenio, árabe y georgiano, y en el siglo V, posiblemente antes del 500, al latín ${ }^{6}$. De esta traducción derivaron los bestiarios latinos, y de estos, a su vez, los bestiarios en lengua vernácula ${ }^{7}$. La hipótesis más aceptada es que fue redactado por un autor desconocido en Alejandría, en el siglo II ${ }^{8}$. Para otros autores, como Wellmann, es sirio y del siglo IV, y recogió las enseñanzas de Orígenes cuando se exilió de Alejandría en Caesarea Stratonis en el siglo III'.

7 En cuanto a la composición, si bien es difícil hablar de filiaciones en una obra que fusiona y se enriquece con numerosos textos y tradiciones, los antecedentes más remotos del Fisiólogo deben rastrearse en la Investigación sobre los animales, de Aristóteles, las Historias de Heródoto, las Moralia de Plutarco, la Historia Natural, de Plinio el viejo, y la Historia de los animales, de Eliano, que si bien fue redactada en el siglo III, recoge materiales, además de los provenientes de Plinio, de autores anteriores cuyas obras se han perdido, y que podrían haber sido también fuentes para nuestro anónimo autor ${ }^{10}$. Puede conjeturarse, además, que se agregó información proveniente de la literatura paradoxográfica griega, como la colección de historias maravillosas de Antígono de Caristos, de la literatura esotérica egipcia, concretamente la Physica kai Mystica de Bolos de Mendes, y quizá también de las narraciones de viajeros, máxime si recordamos la posición privilegiada de Alejandría como enclave cultural y comercial entre Oriente y Occidente. Probablemente, haya habido un texto primitivo que incluyera solamente la materia animal, una especie de tratado de zoología sobre seres existentes, aun los que hoy se consideran fabulosos o imaginarios, y las alegorías moralizantes hayan sido incorporadas posteriormente. Lynn Thorndike y Florence McCullogh sostienen esta hipótesis, apoyándose en la ausencia de alegorías en textos tempranos, como la versión en siríaco del Fisiólogo o los fragmentos conservados en el 
Glosario de Ansileubus (siglo VIII-IX) ${ }^{11}$. La elección de los animales para alegorizar estaría determinada mayormente por su presencia en la Biblia ${ }^{12}$.

¿Cuándo esta combinación de zoología fantástica (o no $)^{13} \mathrm{y}$ alegoría moralizante puede considerarse que se ha transformado en un bestiario? La respuesta es: cuando se introducen adiciones de otras fuentes. Es el número y la extensión de estas lo que constituye los fisiólogos en bestiarios ${ }^{14}$.

9 Las principales fuentes de adiciones son las Etimologías de san Isidoro de Sevilla (siglo VII) y el Hexameron de San Ambrosio (siglo IV) ${ }^{15}$; también el Polyhistor de Solinus, (siglo III d.C), el Pantheologus de Peter de Cornwall (siglo XII) y De rerum naturis et verborum proprietatibus, vasta enciclopedia más conocida como De universo, de Rábano Mauro $(\text { siglo IX })^{16}$.

10 Alegoría y bestiario

11 Examinemos ahora algunos ejemplos extraídos fundamentalmente del Fisiólogo latino y sus derivados para ilustrar de qué manera se produce la alegoresis a partir de las descripciones de los animales.

1) El castor

Dice el Fisiólogo:

"Hay un animal llamado castor, sumamente inocente y sosegado. Sus testículos se utilizan en medicina (...) En las montañas, los cazadores lo acosan a fin de apoderarse de él; el animal, al ver que un cazador lo persigue, se extirpa con los dientes los testículos y se los arroja. Y si luego lo persigue otro cazador, se tiende boca arriba, mostrándose a él; el cazador, viendo que carece de testículos, se aleja de él"17.

14 La autocastración del castor era una creencia difundida desde la antigüedad. Relatos semejantes a éste se encuentran en las Hieroglyphica de Horapollo, la Historia natural de Plinio, la Historia de los animales de Claudio Eliano, y en las Etimologías de San Isidoro. Se suponía que el castoreo, una sustancia muy apreciada por sus virtudes medicinales, estaba contenido en sus testículos ${ }^{18}$. En realidad, es la secreción de las glándulas prepuciales, muy desarrolladas en esta especie, ya que sirven para la demarcación del territorio. Estas glándulas se vacían fácilmente en condiciones de estrés, lo que hace que, aparentemente, desaparezcan: esto fue lo que dio lugar a la creencia de que el animal se arrancaba los testículos (Fig. 1). 


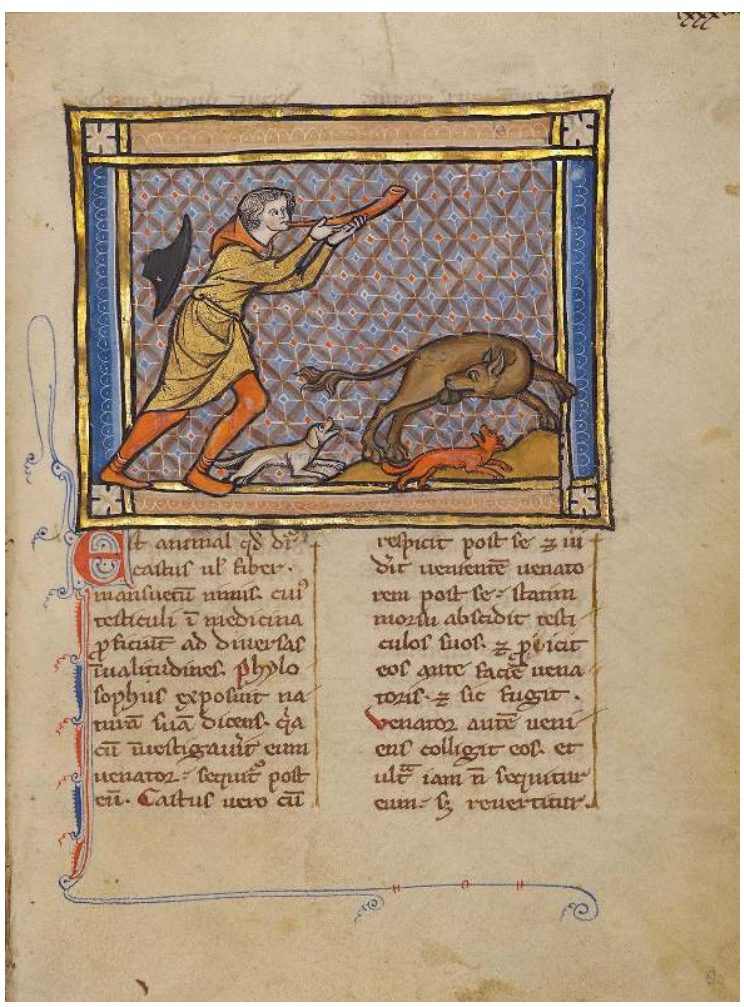

Fig. 1 - Castración del castor acosado por un cazador en un bestiario c. 1270. Ms. Ludwig XV 3 (83.MR.173), fol. 83

(c) The J. Paul Getty Museum Collection [en línea] [consultado el 20 diciembre 2019]. Disponible en HTTP://WWW.gETTY.EDU/ART/COLLECTION/OBJECTS/4806/UNKNOWN-MAKER-A-HUNTER-BLOWINgHIS-HORN-AND-A-BEAVER-FRANCO-FLEMISH-ABOUT-1270/?DZ=0.5000,0.6130,0.92.

\section{A continuación, la interpretación alegórica:}

“¡Oh tú, ciudadano de Dios, que te comportas virilmente! Si das al cazador lo que es suyo, ya no se aproximará a ti. Es decir, si anidan en ti la concupiscencia mala, la codicia, el adulterio, el hurto, extirpa todo eso de ti y arrójaselo al diablo (...) Antes que nada arrojemos al diablo las ignominias de los pecados que haya en nosotros, es decir, sus obras, y demos luego a Dios lo que es de Dios, las promesas de las plegarias, el fruto de nuestras buenas obras".

Como vemos, la construcción alegórica es sencilla: una correspondencia uno a uno, un sentido literal, un sentido alegórico:

\begin{tabular}{|l|l|l|}
\hline Castor & Testículos & Cazador \\
\hline Varón pecador & Pecado: concupiscencia, codicia, hurto, adulterio & Diablo \\
\hline
\end{tabular}

Una alegoresis aún más simple observamos en el Libellus de natura animalium, que drásticamente, aconseja:

"Tratemos con toda nuestra fuerza de alcanzar dicha virtud: a saber que siempre que tengamos algún miembro o alguna cosa muy querida, pero por cuya culpa podemos perecer y ser atrapados por los perros, es decir, por el diablo, sin duda entonces debemos cortar y amputar dicho miembros, tal como está escrito: "Si tu ojo te escandaliza, sácalo y arrójalo lejos de ti" ${ }^{19}$. 

mencionado anteriormente o el bestiario latino en prosa conservado en la Biblioteca universitaria de Cambridge (siglo XII) se plantean las cosas al revés: la comadreja es fecundada por la oreja y concibe por la boca aunque el último aclara la existencia de la versión contraria e introduce otro elemento que se alegoriza, a saber, que la comadreja que vive en una casa, astutamente protege a sus crías trasladándolas noche a noche a una madriguera diferente. La exégesis es la siguiente: "Estas criaturas representan a no pocos de vosotros, que aceptáis de buen grado la palabra de Dios, pero que, entorpecidos por el amor de las cosas terrenas, la relegáis a un lugar inadecuado, y disimuláis lo que oís"

24 Ambos elementos, el semen y las crías, conservan las equivalencias precisadas en el Fisiólogo, pero la alegoría resulta menos forzada al ser el semen-palabra introducido por la oreja y la cría-palabra de Dios repetida por la boca ${ }^{22}$. Sin embargo, la alegorización del ocultamiento de las crías es un poco más compleja y exigida: el lugar inadecuado corresponde a la casa (donde viven las personas y no las comadrejas) y el matiz de disimular (o ignorar) la palabra divina está asimilado a la treta de esconder las crías, disimularlas a la vista de la gente. Posiblemente de este hecho, es decir que el animal traslada a sus crías tomándolas con su boca, se dedujo que paría por la boca (Fig. 2). 


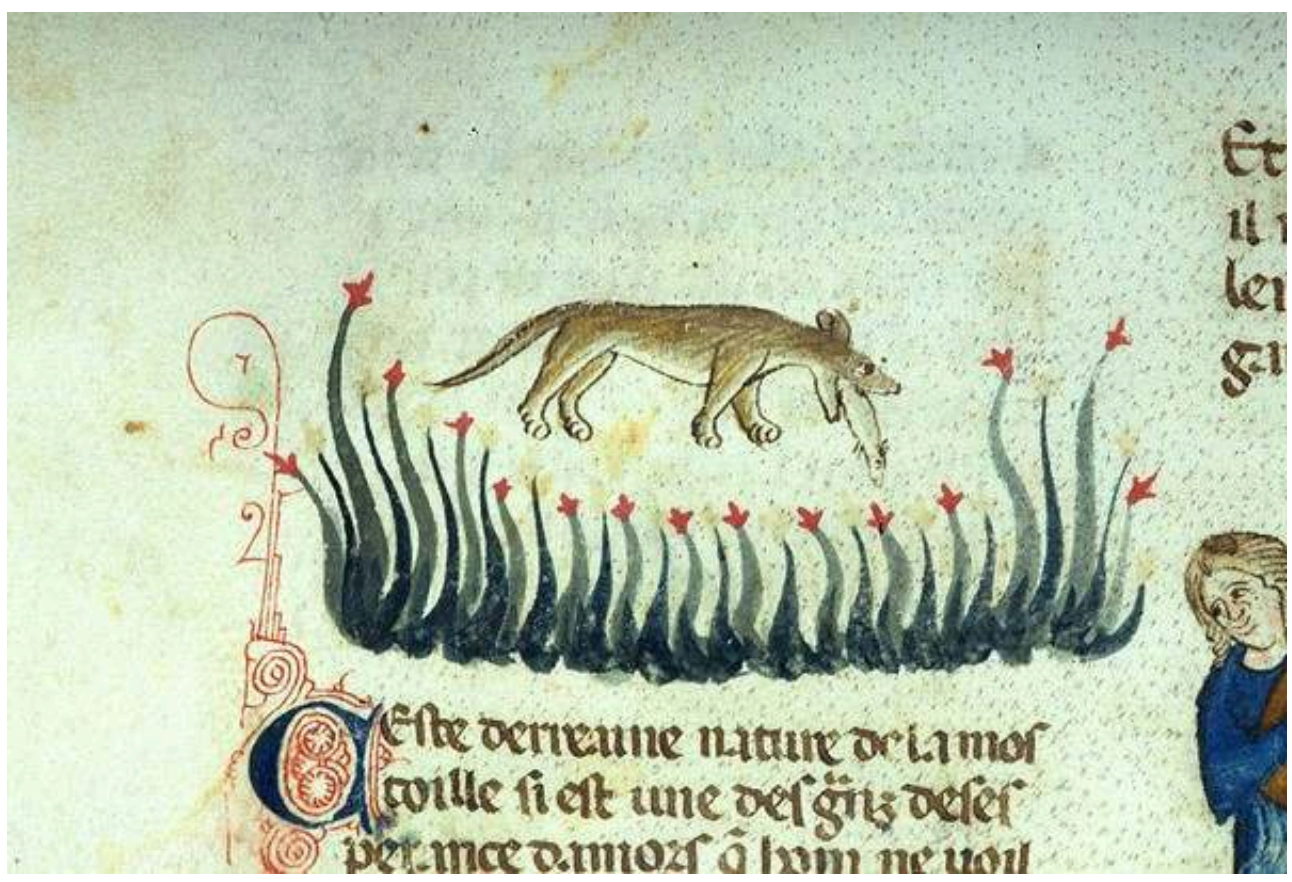

Fig. 2 - Comadreja pariendo por la boca. Bestiaire d'Amour, ca. 1290. MS M.459 fol. 7v.

(C) The Morgan Library \& Museum [en línea] [consultado el 20 diciembre 2019]. Disponible en HTTP:// WWW.gETTY.EDU/ART/COLLECTION/OBJECTS/4806/UNKNOWN-MAKER-A-HUNTER-BLOWINg-HISHORN-AND-A-BEAVER-FRANCO-FLEMISH-ABOUT-1270/?DZ=0.5000,0.6130,0.92.

El Libellus, que corresponde a un momento posterior, fines del siglo XIV o principio del $\mathrm{XV}$, en el cual las alegorías cristianas de los bestiarios ya estaban fijadas, extrae una enseñanza más secular, referida a las ventajas de ser discreto y saber callar: “(...) pues no todo lo que se capta por el oído ha de difundirse siempre por la boca, pues lo malo no ha de divulgarse, sino más bien ha de ocultarse (...)"23.

3) La piedra sóstoros y la perla

El simbolismo de la ostra (la piedra sóstoros) y la perla supone un caso aún más interesante que los precedentes de alegorización cristiana de un conocimiento zoológico, ya que la ostra y la perla están presentes desde la más remota antigüedad en las cosmologías acuáticas ${ }^{24}$. Participan de los poderes sagrados concentrados en las Aguas, la Luna y la Mujer y son emblemas de estas fuerzas: la ostra, por la semejanza de las valvas con la vulva femenina, y por la creencia en que, por la acción de las aguas y la luna, la ostra se preñaba de la perla, y era semejante así a la mujer que lleva al feto en su vientre; la perla, porque en ella se concentraba este doble simbolismo ginecológico y embriológico. La asociación de la perla con la fecundidad se encuentra en diversas culturas, africanas, amerindias, orientales, como Japón, China e India y en las de la cuenca del Mediterráneo. En Grecia es ilustrativo de esta vinculación el nacimiento de Afrodita en una concha. Este significado mágico religioso se pierde progresivamente, y su sustrato perdura como un conocimiento "científico" que en Europa se registra hasta el siglo XVIII ${ }^{25}$. El cristianismo toma estos elementos y los resignifica en clave cristiana. Así, San Efrem se basa en un antiguo mito de origen oriental que explica el origen de la perla como el efecto del rayo que penetra en el mejillón, es decir, el fruto de la unión entre el fuego y el agua, para ilustrar tanto la Inmaculada Concepción como el nacimiento espiritual de Cristo, simbolizado por la perla en el bautismo de fuego ${ }^{26}$. Orígenes, y otros autores después de él, también identifican la perla con Cristo. Este 
proceso de alegorización, en su expresión más elaborada y compleja, es el que hallamos en el Fisiólogo:

“(...) hay en el mar una piedra que se denomina sóstoros. De madrugada, antes del alba, sale la piedra sóstoros a la superficie del mar, abre sus valvas (es decir, su boca) y absorbe el rocío celestial junto con los rayos del sol y de la luna, que están por sobre las estrellas. Así nace la perla de los astros superiores (...) El mar simboliza el mundo; los buceadores, que sacan del fondo del mar la perla, son los santos doctores; los pecadores, los que por su malicia la arrojan al fondo, son cuantos se contraponen a aquéllos; y en el medio de las dos valvas, es decir de las dos alas (hay que entender esto espiritualmente) está el Señor, nuestro Salvador (entre los dos Testamentos, el Antiguo y el Nuevo) que recibe del Cielo su alimento" 27.

El Fisiólogo griego, más específico, aclara que este alimento celestial, este principio fecundador es el Espíritu Santo ${ }^{28}$.

El bestiario de Phillipe de Thaün introduce una interesante variación:

"La perla nace ciertamente en una isla llamada Tapnë [Ceilán]; en esta isla hay piedras que están hechas de tal modo que no tienen boca, juntura ni grieta, sino que son lisas como el hielo. Y deseo que todos sepan muy bien que estas piedras tienen el poder de abrirse por su propia voluntad; reciben el rocío del cielo, y de éste conciben, como si fueran criaturas vivas. Después, vuelven a cerrarse sin rendijas. El rocío permanece en la piedra hasta que se vuelve piedra a su vez, y entretanto permanece allí siempre, como una madre que gesta a su hijo; luego se abre, sale la piedra, y se cierra de tal modo que después no podrá ser abierta, ni se encontrará en ella hendidura alguna (...) La perla que nace del rocío y que ha sido engendrada en piedra significa la "unicidad" de Jesús; la piedra de la que nace, santa María; la perla que nace del rocío significa la gracia dispuesta. Mediante la gracia fue presentado a la Virgen el Hijo de Dios; mediante la gracia tomó la salvación, y mediante la gracia fue concebido. Como la piedra se abre sin fractura, y se une sin rendija, como la piedra transforma el rocío, así fue consagrada la Virgen, así parió y dio a luz. La Virgen, que fue madre de Jesús, concibió virgen, parió virgen, virgen permaneció y permanecerá" 29 (Fig. 3).

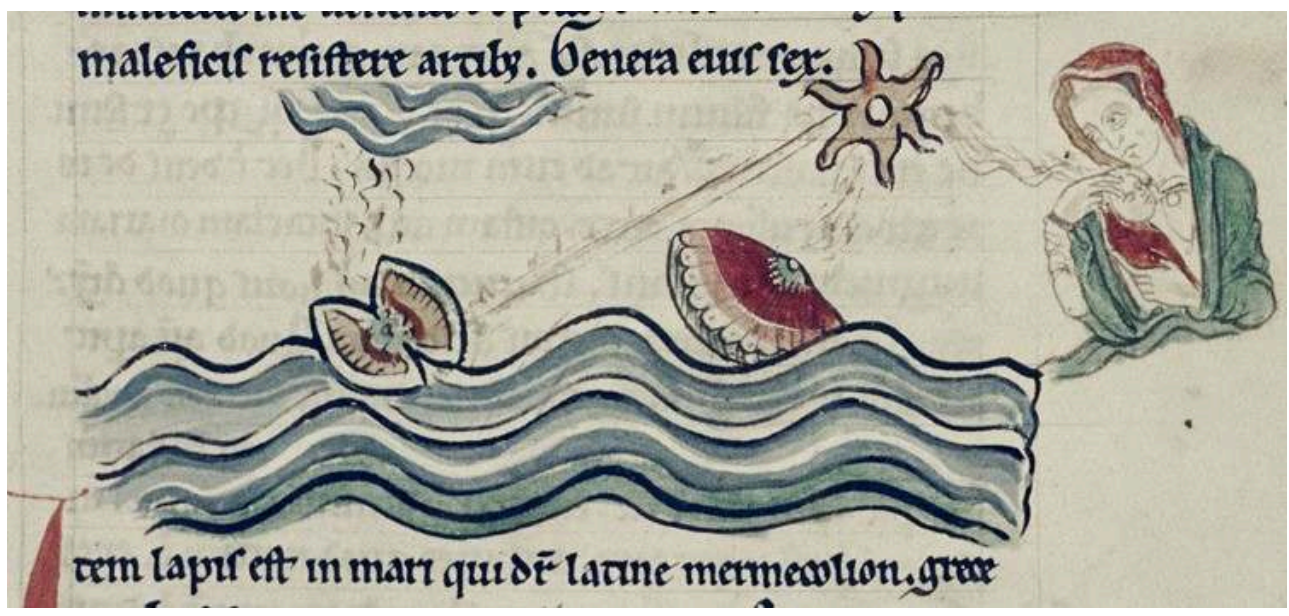

Fig. 3 - Ostra, perla, Virgen y niño, Bestiario, siglo XIII, segundo cuarto. MS. Bodley 602, Folio 34r. (c) Bodleian Library, University of Oxford, [en línea] [consultado el 30 diciembre 2019] Disponible en HTTPS://DIgITAL.BODLEIAN.OX.AC.UK/INQUIRE/P/72B4CC9E-128B-4969-A39B-9D29875BC33B.

Observemos las correspondencias: 


\begin{tabular}{|l|l|l|l|l|}
\hline $\begin{array}{l}\text { Piedra sostoros (Fis.) } \\
\text { Piedra sin juntura (P.T.) }\end{array}$ & Perla & $\begin{array}{l}\text { Rocío, rayos de la luna, } \\
\text { rayos del sol. }\end{array}$ & Buceadores & Mar \\
\hline $\begin{array}{l}\text { Antiguo y Nuevo } \\
\text { Testamento (Fis.) }\end{array}$ & Jesucristo & $\begin{array}{l}\text { Espíritu santo } \\
\text { (alimento celestial) }\end{array}$ & $\begin{array}{l}\text { Santos doctores (los } \\
\text { profetas) }\end{array}$ & Mundo \\
\hline Virgen María (P.T) & Jesucristo & $\begin{array}{l}\text { Gracia divina } \\
\text { (mediada por el S.S) }\end{array}$ & - & - \\
\hline
\end{tabular}

Fis: Fisiólogo / P.T: Phillipe de Thaün, bestiario.

Es llamativo como un primitivo símbolo sexual pagano es vaciado de contenido de esta índole para refuncionalizarlo: en el Fisiólogo latino las valvas se transforman en alas cuyo simbolismo espiritual es evidente (pensemos, por ejemplo, las imágenes que representan al Espíritu Santo) justamente para "entender esto espiritualmente"; Sublimada la ostra, ya puede ser alegorizada como los dos Testamentos. En el bestiario de Philippe de Thaün, la condición de bivalvo y por tanto de animalidad de la ostra desaparece y se transforma en una piedra "sin junturas"; toda posible evocación de la ostra como órgano sexual femenino se desvanece, ya que sería impropio asociar un símbolo erótico como este con la virginidad de María: la concha hueca debe, necesariamente, transformarse en algo privado de animalidad como la piedra maciza, donde nada, salvo algo tan intangible como la Divina Gracia, pueda penetrar.

4) Elefante

Dice el Fisiólogo:

"Existe un animal llamado elefante. No siente la concupiscencia del coito (...) Si desea tener hijos, va a Oriente, cerca del Paraíso. Hay allí un árbol llamado mandrágora. Acude allí con su hembra. Come ésta del árbol en primer término y da de él también al macho, a quien seduce mientras come. Y tan pronto como el macho ha terminado de comer, concibe la hembra en su útero. Llegado el tiempo del parto, la hembra se introduce en un lago y cuando el agua le llega a las ubres, sobreviene el parto y deja caer su hijo sobre las aguas. Nada éste entonces, se aproxima a las patas traseras de la madre, encuentra las ubres y mama. El elefante, entretanto, custodia a la parturienta a causa de la serpiente, porque el elefante es enemigo de la serpiente (...).

Ésta es la peculiaridad del elefante: si cae, no se puede levantar. ¿Cómo puede caer, si se apoya en un árbol? Como no tiene coyunturas en las rodillas, ha de colocarse así si quiere dormir. Pero el cazador que quiere atraparlo, corta el árbol contra el cual el elefante acostumbra recostarse, un poco más abajo de la mitad; llega él entonces, se recuesta, se quiebra el árbol y caen al suelo árbol y elefante. Clama el elefante, al no poder levantarse: acude inmediatamente en su socorro otro gran elefante, pero tampoco puede levantarlo; claman juntos los dos y acuden en su ayuda otros doce elefantes, pero ni aún entre todos pueden levantar al caído. Claman entonces otra vez todos a una y llega finalmente un pequeño elefante, que introduce suavemente la trompa por debajo del caído y lo levanta. Este pequeño elefante tiene una peculiaridad: dondequiera se queme algo de su pelo o de sus huesos, ni dragón ni maleficio alguno tiene acceso" ${ }^{30}$.

En este caso, el texto a alegorizar está dividido en dos narraciones breves, cada una de las cuales concluye con una referencia a la serpiente o al dragón, animales que son equivalentes ${ }^{31}$. Cada pequeña narración es la alegoría de un gran relato: la Caída y la Redención, respectivamente. En la primera, la pareja de elefantes, según el Fisiólogo, 
simboliza a Adán y Eva, inocentes antes de probar el fruto del árbol "la mandrágora espiritual", y al probarla, Eva queda "grávida de males", es decir se produce la expulsión del Paraíso. Conoce Adán a su mujer y ésta pare a Caín "sobre las aguas vituperables". La intervención de la serpiente no está representada directamente como la tentadora, sino como la enemiga que los separa del Señor: "Inmediatamente el dragón los destruyó y los apartó de la virtud, es decir, de la obediencia al Señor”. En el segundo relato, la caída concreta del elefante simboliza la Caída de Adán y Eva, que claman a Dios: no los redime de su caída ni la Ley mosaica (el gran elefante) ni el coro de los profetas (los doce elefantes); sólo lo logra "el santo y espiritual elefante", Jesucristo:

"Nuestro Señor Jesucristo, que, siendo el mayor de todos, se convirtió en el más pequeño: pues se humilló, obedeciendo hasta la muerte, a fin de elevar al hombre, como espiritual samaritano, que nos colocó sobre su asno (es decir, sobre su cuerpo): pues Él tomó sobre sí nuestras enfermedades y cargó con nuestras miserias. Samaritano en hebreo se interpreta custodio; del cual dice David en el salmo CXIV: Custodio de los niños es el Señor. Pues allí donde Nuestro Señor está presente, ni el dragón ni otro mal alguno pueden acercarse".

En estas dos secciones puede sospecharse un reordenamiento, fusión y reescritura de conocimientos científicos ${ }^{32}$ que figuraban en las posibles fuentes, algunas conocidas, otras sospechadas o perdidas, del Fisiólogo. Por ejemplo, la castidad del elefante. En la Historia de los animales, de Claudio Eliano, se afirma que el elefante copula una sola vez en la vida, sólo para procrear, y luego del servicio, se desentiende de la hembra. Elige para tal fin lugares apartados, escondidos a la vista de sus congéneres ${ }^{33}$. Plinio también destaca que "por pudor no se aparean sino a escondidas"34. Aristóteles, en su Investigación sobre los animales, señala también la preferencia por sitios alejados, cercanos a las orillas de ríos ${ }^{35}$. Posiblemente sea este hecho el que inspiró el relato de la migración al Paraíso para la cópula. No está claro el origen del mito de la gestación por obra de la mandrágora que aparece en el Fisiólogo. Que sea una mandrágora y no una manzana el fruto prohibido tiene su sentido: la mandrágora era utilizada como afrodisíaco y además se le atribuía la propiedad de hacer fecundas a las mujeres ${ }^{36}$. A pesar de la concepción sin coito, es necesaria la mediación del deseo provocado por la ingesta del fruto para que la que los castos animales "queden seducidos", como se lee en el Bestiario de Cambridge, y la hembra, entonces, conciba. ${ }^{37}$ En realidad, no es un árbol sino una hierba, conocida también como manzana de Satán, planta de Circe o manzana de amor, lo que permite asociarla con la manzana adánica. Para fines medicinales, fundamentalmente se utilizaba la raíz, y no los frutos, unas bayas naranjas (Fig. 4). Posiblemente se hayan fusionado diversos datos provenientes de las fuentes clásicas sobre la copulación de los elefantes, con otros acerca de la mandrágora provenientes de las materias médicas ${ }^{38}$. De esta manera la sumatoria del coito en lugar retirado, la falta de deseo sexual y la planta afrodisíaca o inductora de la concepción, permitió construir una narración susceptible de convertirse en alegoría de la tentación y la caída. Muchas de las ilustraciones presentes en los manuscritos tienen como elementos constantes el río del paraíso, el árbol, la mandrágora ${ }^{39}$. Quizás el río esté relacionado con la cercanía al agua que busca el elefante para el apareamiento, según Aristóteles. 


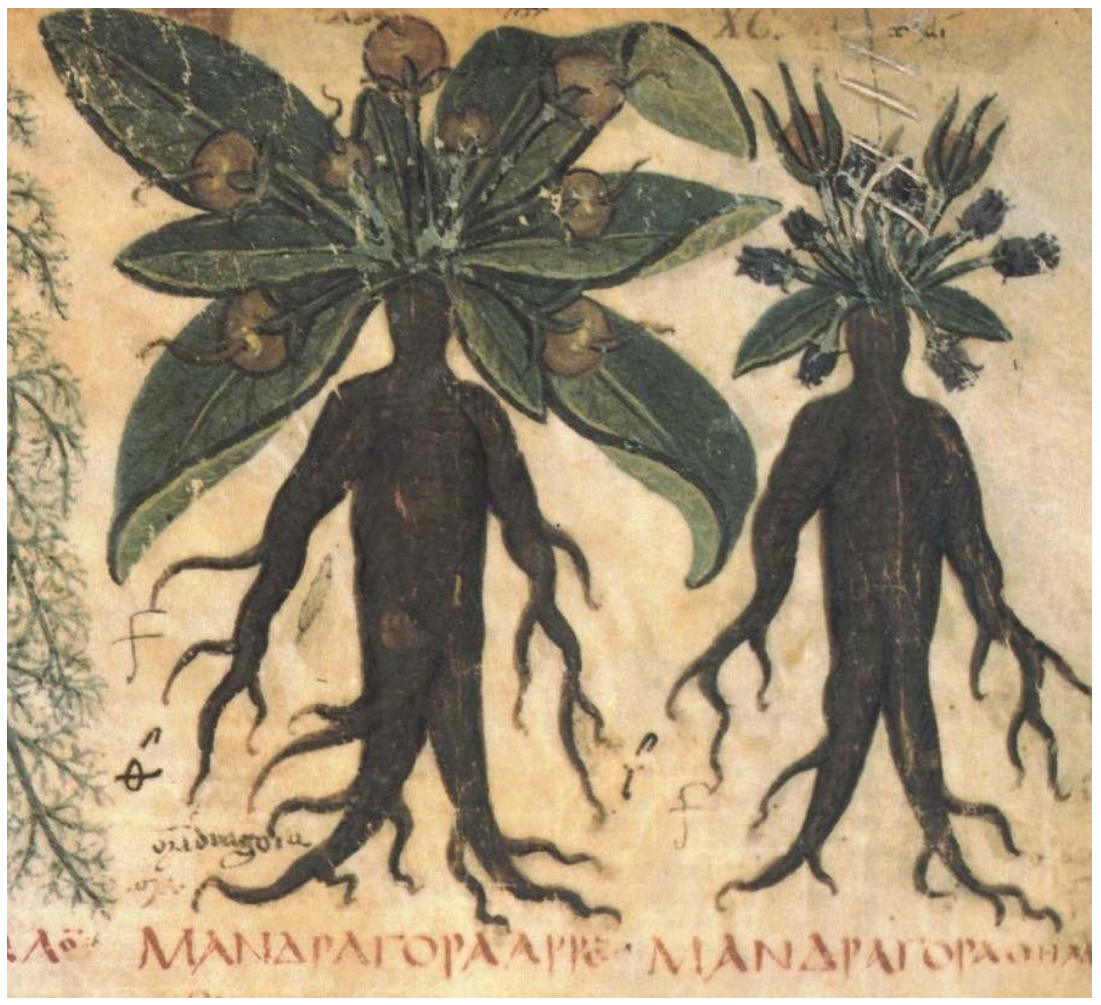

Fig.4 - Mandrágora officinalis, Dioscorides, De materia medica, sigloVII, Cod Gr 1 f.90.

(c) Nápoles, Biblioteca Nazionale. GONZÁLEZ HERNANDO, Irene y HERNÁNDEZ PÉREZ, Azucena, "Mandrágora", Base de datos digital de iconografía medieval. Universidad Complutense de Madrid [en línea][consultado el 27 diciembre 2019] Disponible en HTTPS://WwW.UCM.ES/ BDICONOgRAFIAMEDIEVAL/LA-MANDRAgORA.

El parto en el agua aparece en las Etimologías de San Isidoro de Sevilla, como una manera de proteger a la cría del dragón, ancestral enemigo del elefante ${ }^{40}$. Para Plinio este enemigo no es un dragón, sino una gran serpiente nativa de la India y la causa de la enemistad es que el reptil desea calmar su ardiente sed con la sangre fría del paquidermo ${ }^{41}$. Para saciarla, lo acechaba escondida en las aguas $\mathrm{y}$, cuando la víctima bajaba a beber, se enrollaba en su cuerpo, mordía su oreja y lo desangraba ${ }^{42}$. En el proceso de alegoresis se conjugan el simbolismo usual de la serpiente, Satán, el enemigo de la humanidad, y el del agua, que no tiene aquí un sentido de purificación y renacimiento como en el bautismo ${ }^{43}$, sino el opuesto y complementario de muerte y disolución ${ }^{44}$ : son "las aguas vituperables", significado reforzado por la cita siguiente del salmo 69, versículo 1, "Sálvame, porque las aguas se introdujeron hasta lo más hondo de mi alma". El texto concentra en el agua tres aspectos negativos: el nacimiento de Caín, el primer fratricida, la amenaza del demonio (representado por la serpiente) y el pecado que anega el alma (Fig. 5). 


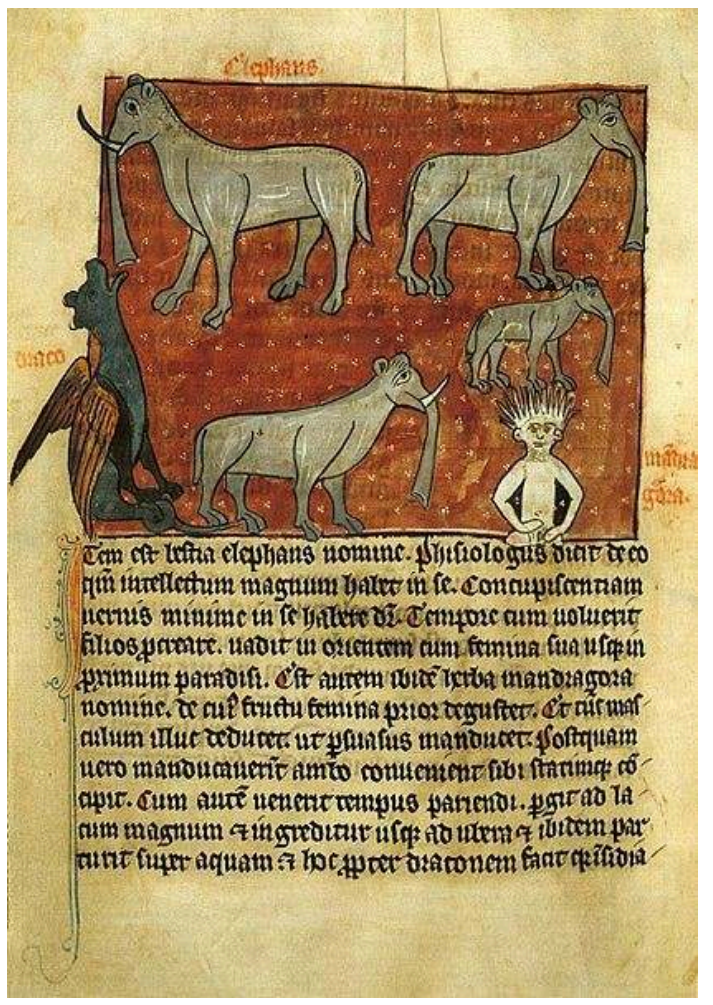

Fig. 5 - el PARTO DE LA ELEFANTA. SLOANE MS 278, F48v, SIgLO XIII, SEgUndo o TeRCER CUARTO.

(c) British Library [en línea]. Wikimedia Commons, the free media repository, 2015 [consultado el 31 diciembre 2019]. Disponible en HTTPS://COMMONS.WIKIMEDIA.ORg/W/INDEX.PHP? TITLE=FILE:SLOANE278_F.48V_ELEPHANTS,DRAgON,ANDMANDRAKE.JPg\&OLDID=154968818.

Toda la segunda narración descansa sobre el difundido error sobre la falta de rodillas del elefante, contra lo que afirmaba Aristóteles en tal sentido. Diodoro Sículo en Biblioteca histórica y Estrabón en su Geografía, ambos autores del siglo I A.C, sostienen esta peculiaridad anatómica del paquidermo ${ }^{45}$, que se repetirá en todas las descripciones posteriores incluso hasta entrado el siglo XVI, y que alimentará la leyenda de la caza por serruchamiento del árbol contra el cual se apoya para dormir ${ }^{46}$. Claudio Eliano, por el contrario, describe una escena más realista: los cazadores cavan zanjas, hacia las cuales van arreando a los animales asustándolos con el ruido de trompetas o con antorchas encendidas, hasta que caen en ellas ${ }^{47}$. Si los elefantes advierten la zanja en su huída, el más grande de ellos se mete dentro y oficia de puente; una vez que pasó la manada, ayudan a salir al compañero, "desde arriba, uno le ofrece la pata para que enrolle allí la trompa; los otros elefantes llevan hierbas y ramas" ${ }^{48}$ y así el elefante se sube a las ramas y sale de la zanja. Plinio describe una escena similar ${ }^{49}$. También otros relatos dan cuenta del comportamiento solidario de la manada, cómo atienden a los enfermos, cómo jamás abandonan a los débiles ni aun cuando son perseguidos, cómo los jóvenes protegen a los ancianos ${ }^{50}$. En el Bestiario de Cambridge ${ }^{51}$ se afirma que un viajero hindú aseguraba haber visto unos ochenta y siete elefantes en tierra, caídos uno tras otro por haber intentado levantar a un primero derrumbado por apoyarse en el árbol serruchado por el cazador. Podemos hipotetizar que hubo alguna fuente imposible de establecer, que puede haber incluido este relato del viajero, que, junto a las descripciones de Claudio Eliano o similares debe haber servido de base a la narración del rescate solidario que permitió construir la fábula de la caída de los dos primeros elefantes, los siguientes doce y el rescate por obra del más pequeño ${ }^{52}$. Es 
curioso que, cuando las obras de Aristóteles reingresaron en el occidente europeo vía el mundo árabe, la equivocación sobre la ausencia de articulaciones en las patas del elefante se mantuvo; en el Maqāla Tashtamil 'alā Fusūl Min kitāb al-Hayawān Li-Aristū, el Tratado comprendiendo extractos del Libro de los animales de Aristóteles ${ }^{53}$, atribuído a Maimónides, puede leerse que "cada cuadrúpedo vivíparo dobla sus patas delanteras hacia delante y sus patas traseras hacia atrás, excepto el elefante, que no puede doblar ninguna de sus cuatro patas debido al peso de su cuerpo". En Investigación sobre los animales, en cambio, Aristóteles afirma que el elefante "se sienta y dobla las piernas, si bien que, debido a su peso, no puede doblar los dos lados a la vez" ${ }^{54}$. La perpetuación de este yerro puede deberse a errores en la traducción original del griego al árabe, realizada por Hunain b. Ishāq, sobre la que está basado el Tratado, o errores de interpretación del propio Maimónides ${ }^{55}$. De todas formas, hay que tener en cuenta que en Europa, durante el medioevo solamente se conocieron tres elefantes, uno, Abul Abbas, regalado por Harun al-Rashid a Carlomagno en el año 797, otro, el que obsequió el Sultán de Egipto Al Kamil a Federico II Hohenstaufen en 1229, y el último, el que como presente diplomático le ofreciera Luis el Piadoso a Enrique II de Inglaterra en 1255 y que murió de frío dos años más tarde. Realmente, no había mayor información que las fuentes escritas y esto se reflejó en las representaciones de los artistas: muchas veces en vez de trompa tenían pico y las patas a veces se dibujaban con los garrones y los codos angulados como los de otros mamíferos, como se ve en la figura 6, o bien rectas, como en la ilustración del elefante de Cremona de la Crónica de Mateo Paris, de mediados del siglo XIII (Fig. 7) ${ }^{56}$.

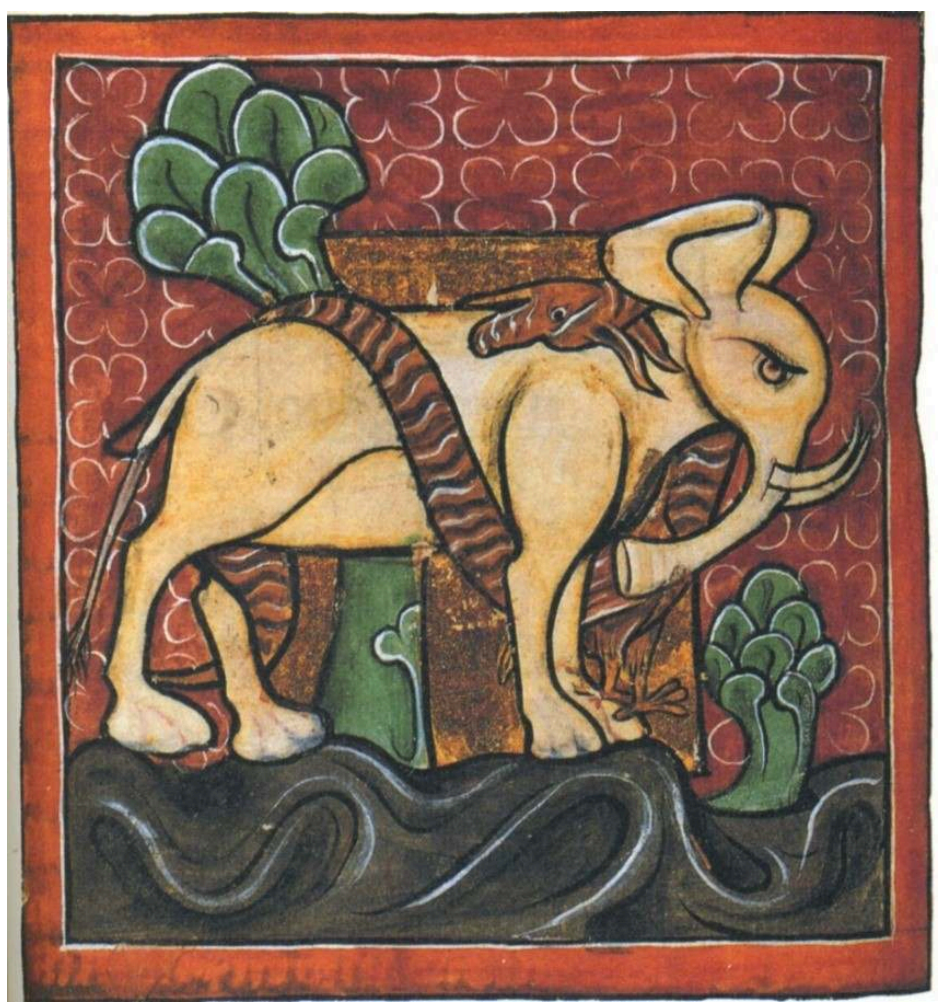

Fig. 6 - Elefante atacado por el dragón. Bestiario ca. 1225-1250. MS. Bodley 764.

(c) Bodleian Library, University of Oxford [en línea]. Wikimedia Commons, the free media repository, 2016 [consultado 31 diciembre 2019]. Disponible en HTTPS://COMMONS.WIKIMEDIA.ORg/w/

INDEX.PHP?TITLE=FILE:83-OXFORD_BODLEY_764-_ELEFANTE.JPg\&OLDID=196331031 


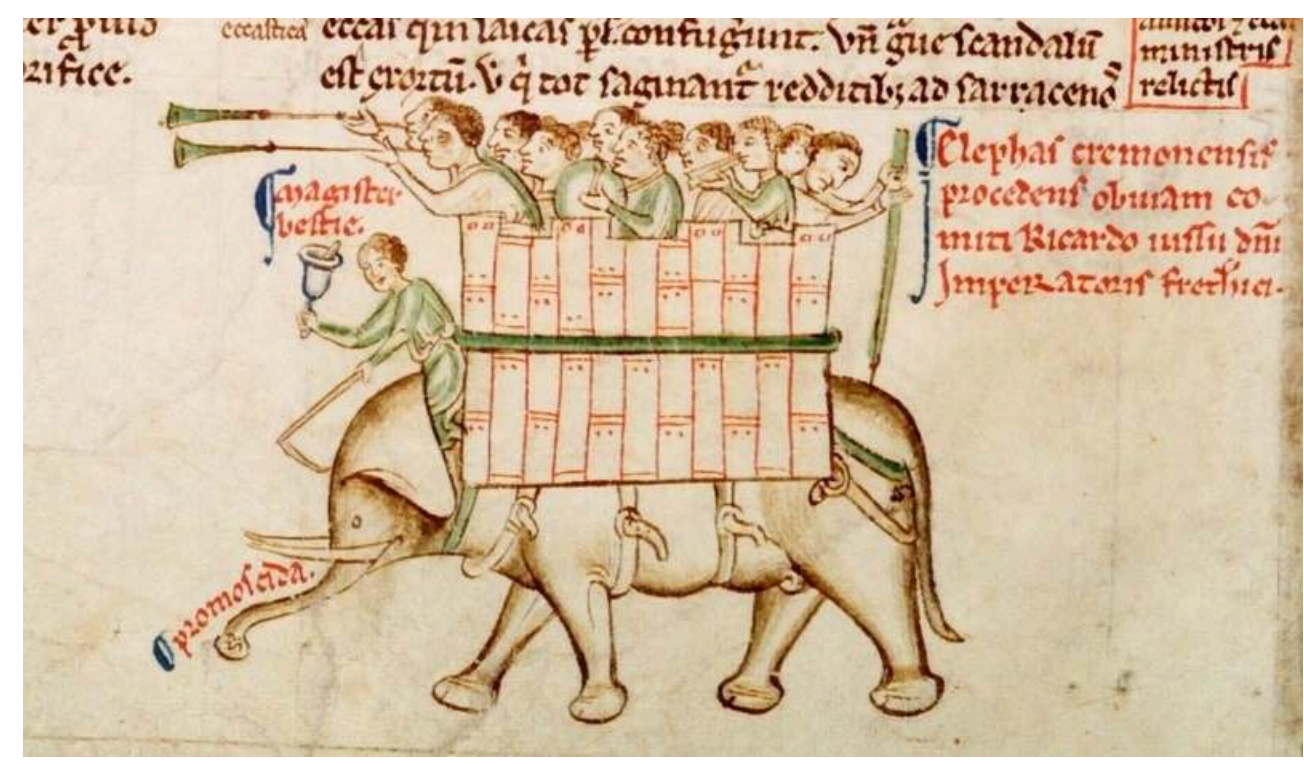

Fig.7 - Mateo de París Chronica Maiora II, 1235 a 1259, MS 16, fol. 151 v.

(c) Parker Library, Corpus Christi College, Cambridge [en línea]. Wikimedia Commons, the free media repository, 2018 [consultado el 31 diciembre 2019]. Disponible en HTTPS://COMMONS.WIKIMEDIA.oRg/ W/INDEX.PHP?

TITLE=FILE:MATTHEW_PARIS_ELEPHANT_FROM_PARKER_MS_16_FOL_151V.JPg\&OLDID=326905485

Finalmente, la cualidad de los pelos y los huesos quemados del pequeño elefante de repeler al dragón o a la serpiente, provienen seguramente de aseveraciones como las de Eliano. quien afirma que la grasa del elefante tiene la propiedad de repeler los animales venenosos, quemada o untada sobre el cuerpo ${ }^{57}$.

Podemos observar, entonces, como el sentido literal de las fuentes es reordenado en una narración que permite expresar un sentido profundo, un significado adicional a la realidad transmitida por los textos. La Naturaleza, a través del elefante, evoca los dos momentos capitales de la historia de la humanidad, la Caída y la Redención, y recuerda, encarnado en la serpiente o el dragón, la amenaza constante del demonio.

Estos ejemplos muestran diversos grados de complejidad en la construcción de la alegoría: desde una relación uno a uno, en mitos como el de la autocastración del castor y el de la concepción y el parto de la comadreja, pasando por elaboraciones un poco más complejas como las de la ostra, donde se resignifica un símbolo pagano, hasta llegar al elefante, donde todo un corpus de información zoológica es narrativizado para componer la alegoría de la historia del hombre.

El mundo según Platón

Para entender cuál es la visión del mundo que subyace a esta forma de exégesis, es imposible soslayar a Platón y a las corrientes a la que dio origen su filosofía en los primeros siglos de la era cristiana, y a su continuación durante la Edad Media. La filosofía del ateniense era particularmente atractiva para los primeros Padres alejandrinos, ya que sus nociones fundamentales se prestaban como base teórica del pensamiento cristiano, a saber, la chorismós o separación de la realidad en dos mundos, inmanente y trascendente, de los cuales el primero participa (métexis) o es una mera copia del segundo y la presencia del alma humana en este mundo inmanente, que es afín a lo trascendente e inmortal y que actúa como mediadora entre ambos mundos. Estos conceptos platónicos fueron reelaborados en Alejandría, en el siglo III por dos discípulos de Amonio Sacas: uno, pagano, Plotino, otro, cristiano, Orígenes. En ambos 
encontramos un tipo de platonismo que presenta algunas novedades con respecto al pensamiento de Platón y al de los platónicos académicos que los precedieron: una instancia más allá del ser, el Uno para Plotino, Dios, para Orígenes, de la cual procede todo en el orden del ser, como una cascada ontológica que va del principio a lo principiado. En este proceso, llamado por Plotino emanación y por Orígenes creación, lo que se emana o crea no es diferente de su principio, uno, inefable y perfecto, sino que es una explicitación de su misma unidad en una serie de instancias hasta llegar al grado de mayor degradación ontológica, que es la materia, en la que, a pesar de esta caída está plenamente presente. El mundo es, para Orígenes, una creación ex nihilo, hecha por Dios por la manifestación de su Verbo, en el cual están las formas vivientes de todas las cosas y es un mediador entre él y sus creaturas. En tanto todo participa de la naturaleza divina, todas las cosas representan un signo de la divinidad que es preciso descifrar. No sólo es la Biblia el Texto por excelencia para la exégesis alegórica sino también el libro de la naturaleza ${ }^{58}$.

Los Padres latinos, que no tuvieron conocimiento directo de las obras de Platón, accedieron a este por medio de un fragmento de la traducción de Cicerón del Timeo, por la traducción, también fragmentaria, de Calcidio, y por las Enéadas de Plotino, escritas por su discípulo Porfirio y traducidas al latín por Mario Victorino. El neoplatonismo de San Agustín, que no sabía griego, a diferencia de su maestro San Ambrosio, tuvo como origen estas lecturas. Por este último, además, tuvo acceso a la literatura patrística, que el obispo de Milán había leído en su lengua original y a una clave hermeneútica para entender el lenguaje alegórico en que está cifrada la Escritura. A diferencia de Orígenes y Plotino, Agustín de Hipona no consideraba a la materia como ontológicamente degradada; el mundo es material porque Dios así lo quiso, y en tanto creación divina, es bueno. Al igual que aquéllos, también tenía la idea de que la relación entre el uno y lo múltiple, era de participación, pero es una participación débil. Dios pone su vestigio o impronta en las creaturas bajo la forma de tres aspectos que los constituyen como entes y que reflejan la estructura trinitaria divina pero no tienen su misma naturaleza ${ }^{59}$. Y como Orígenes, y tras él toda la Edad Media hasta Guillermo de Ockham, sostuvo que Dios había creado el mundo a través de su Lógos, que contiene los modelos arquetípicos de todo lo que existe, existió y puede existir, las Ideas platónicas. Sin embargo, la exégesis agustiniana difiere de la origeniana en que no se basa tanto en develar la relación entre la cosa y su arquetipo como en indagar sobre las posibilidades de cualquier realidad natural para ser un ejemplo que ilumine la interpretación de las verdades reveladas, en la medida en que el exégeta establezca una semejanza congruente entre ellas ${ }^{60}$.

La influencia del neoplatonismo de San Agustín fue predominante a lo largo de todo el medioevo, alcanzó su punto más alto en lo que a la interpretación del mundo se refiere, con el platonismo elaborado de la escuela de Chartres, para decaer a fines del siglo XII con el reingreso de Aristóteles a Occidente. Un síntoma precoz del agotamiento del platonismo fue, en esa centuria, la famosa querella de los universales, entre realistas y nominalistas. La solución de Pedro Abelardo, al definir el universal como el significado de un término abstraído de las características comunes de un conjunto de individuos, ya era más cercana al pensamiento del Liceo que al de la Academia. El terreno para el arraigo de la filosofía aristotélica, que florecería en el próximo siglo, se estaba preparando.

El mundo según Aristóteles 

el griego al latín: los libri naturales (Historia de los animales, Física, Sobre el cielo, De la generación y corrupción, etc.) los cuatro primeros libros de la Metafísica y dos libros de la Ética nicomaquea. La traducción de los manuscritos aristotélicos supuso una verdadera revolución en el pensamiento medieval ya que significó el pasaje de una visión del mundo trascendente a otra inmanente. Ya no habrá esencias separadas de las cosas, sino que lo único verdaderamente existente serán las sustancias individuales. El punto de vista aristotélico era esencialmente naturalista y basado en la experiencia sensible. Los hechos del mundo natural dejarán de ser signos que guíen a una verdad oculta que hay que descubrir, para transformarse en fenómenos que es preciso explicar. El avance de la ciencia y de la técnica, sobre todo bajo la influencia del mundo árabe, requería una fundamentación filosófica que el neoplatonismo no le podía dar. La escolástica del siglo XIII, con sus dos grandes exponentes, Alberto Magno y su discípulo Tomás de Aquino, fue el método que, basado en las leyes de la razón, permitió desarrollar esos fundamentos ${ }^{61}$. En principio, la filosofía apoya a la teología, la razón va al encuentro de la fe para iluminarla, pero luego también sale a buscar la experiencia para demostrar la verdad de la razón. La escuela inglesa, de la que el franciscano Roger Bacon será el principal exponente, intentará la primera gran síntesis entre razón y experiencia, teoría y práctica. Pero será necesario que la filosofía se libere de las ataduras de la teología para que la ciencia siga avanzando. El divorcio entre la razón y la fe, anunciado por el averroísmo del siglo XIII, culminará con el nominalismo de Guillermo de Ockham en el siglo XIV. Para el franciscano de Oxford, los universales sólo existen en el alma del sujeto cognoscente, los únicos con existencia real son los entes individuales, y su conocimiento se alcanza por medio de la intuición sensible. En tanto fuera del campo de la experiencia, las cuestiones de fe no son demostrables; dependen de la revelación y quedan circunscriptas al ámbito de la teología ${ }^{62}$.

las traducciones a lengua vulgar y el Fisiólogo es el libro de historia animal más leído. También es el momento en que se inicia su decadencia. Por un lado, hacia el siglo XIII, las alegorías animales ya están cristalizadas en su forma y fijadas en su significado, y se prestan a ser reutilizadas y parodiadas en libros como el Bestiario de amor, de Richard de Fournival, y sus derivaciones, el Bestiario de amor rimado, la Respuesta al Bestiario de amor, etc. En el Bestiario de amor, los animales servirán a intereses más mundanos y menos edificantes como ganarse el favor de una dama. Así, los testículos del castor simbolizarán los favores de la dama y serán, por lo tanto, el remedio para la muerte de amor; retienen algo de su primitiva significación pecaminosa, pero subvertida en un sentido positivo ${ }^{63}$. Aún más irreverente, para Richard el semen que penetra en la oreja de la comadreja no será la palabra divina sino las hermosas palabras del amante ${ }^{64}$. El momento de escritura coincide con el auge del aristotelismo y es probable que en estas obras no solamente asistamos a la decadencia de una visión neoplatónica del mundo, sino también a los efectos de la influencia del naturalismo averroísta en la mentalidad, en este caso sexual, de la época.

tra parte, posteriormente, el desarrollo de la ciencia experimental hacía cada vez más insostenible el mantenimiento de datos que se revelaban inexactos en contraste 
con la experiencia. Ya en los albores de la modernidad, cuando el mundo cerrado medieval estaba a punto de dejar paso al universo infinito, el conocimiento no podía ya basarse en las auctoritas, ni siquiera en la del Filósofo, sino en la propia observación del hombre. Por ejemplo, en sus comentarios a la Materia médica de Dioscórides, Andrés Laguna (siglo XVI) sobre la creencia en la autocastración del castor, dice:

"Los que dizen que aqueste animal redime su vida con los compañoncicos, por los cuales es acossado: y que à bocados yendo huyendose los arranca, y los dexa a los cazadores, falsamente se lo levantan: visto que no puede alçanzar à ellos, por estar encogidos y retirados: y aun que alcançasse, no lleva el cuytadillo esse espacio, y antes dexaria los ojos, que tal prenda" ${ }^{65}$.

51 Sólo el elefante, que no fue bien conocido en Europa hasta las grandes expediciones de los siglos XVIII y XIX, continúa sin rodillas. En el Libro III de La varia commesuración para la escultura y la arquitectura, del orfebre Juan de Arfe, editado en Sevilla en 1587, obra que en sí misma constituye un pequeño bestiario, con detalladas descripciones de los animales, acompañadas de proporciones y medidas que demuestran una fina capacidad de observación, puede leerse sobre el elefante "No tiene por las piernas dobladura" y “(...) las piernas gruesas, y sin coyuntura hasta los pies" 66 .

A pesar de la decadencia de la alegoría aplicada a los animales, dentro de la literatura mística española estos todavía servirán a la edificación religiosa. La Introducción del símbolo de la $\mathrm{Fe}$ (1583), del dominico fray Luis de Granada, presenta muchos puntos de contacto con las grandes sumas medievales. El tratado desarrolla la prueba de la existencia de Dios fundada en la finalidad y perfección de sus criaturas, de los elementos y de los fenómenos naturales. La primera de sus cinco partes trata sobre "la creación del mundo para venir por las criaturas al conocimiento del Criador y de sus divinas perfecciones". Muy medieval en la forma y en las fuentes (Plinio, Solinus, San Agustín, San Ambrosio), sin embargo deja traslucir el momento renacentista en que se plasmó. En el capítulo XVI, "De la habilidades y armas que los animales tienen para defenderse", el castor es convocado nuevamente a mutilarse, pero ya no para demostrar la necesidad de evitar el pecado sino para destacar la grandeza de la divina providencia que le da al animal "inclinaciones y naturales instintos para todo lo que conviene a su conservación y defensión"67. Si bien el conocimiento que se invoca es medieval, su interpretación y explicación naturalística, aun mediada por la voluntad divina, no lo es; parece presagiar algo del pensamiento evolucionista de los siglos posteriores.

53 Las imágenes de los bestiarios, ya desprovistas de su enseñanza moral, persistirán como imágenes literarias. En la Fábula de Polifemo y Galatea (1613), de Luis de Góngora, el cíclope dice a la ninfa:

“¡oh, bella Galatea, más suave que los claveles que tronchó la Aurora; blanca más que las plumas de aquel ave que dulce muere y en las aguas mora; igual en pompa al pájaro que, grave, su manto azul de tantos ojos dora cuantas el celestial zafiro estrellas! ¡Oh, tú que en dos incluyes las más bellas! Deja las ondas, deja el rubio coro de las hijas de Tetis, y el mar vea cuando niega la luz un carro de oro, que en dos la restituye Galatea.

Pisa la arena, que en la arena adore 
cuantas el blanco pie conchas platea,

cuyo bello contacto puede hacerlas,

sin concebir rocío, parir perlas" ${ }^{68}$.

Como vemos, las imágenes de la blancura de Galatea culminan con la apelación a la perla y la piedra sóstoros. Ni símbolo crístico, evángelico o mariano, la perla y la ostra por obra de la pluma del poeta construyen un sentido más cercano a su originario simbolismo pagano. Hay que hacer notar, además, que en estas dos estrofas, además de la ostra, son invocadas otros dos protagonistas de los bestiarios, el cisne "que dulce muere [canta antes de morir] y en las aguas mora" y el pavo real que "su manto azul de tantos ojos dora". El culteranismo gongorino abrevó también en la rica fuente de los bestiarios medievales.

\section{El fin de las bestias}

Sin nada de su ropaje moralizante, las bestias seguirán entre nosotros hasta nuestro siglo, cuando repitamos, sin saberlo, viejos saberes medievales. Alabaremos la memoria de elefante, la vista del águila o la del lince, condenaremos la ingratitud de los cuervos, celebraremos la fidelidad del perro y el amor de los tórtolos. Pero ya no podrán ser una pista para el desciframiento del enigma de la creación. Cada época es deudora de su visión del mundo. Sólo el medioevo, con ocho siglos de predominio neoplatónico, podía ver más allá de la verdad de su existencia física un indicio del verdadero sentido del cosmos. Sólo el medioevo, con su fe ciega en las autoridades, el testimonio oral y la palabra escrita podía aceptar la absurda anatomía de un mimercoleón ${ }^{69}$ o la increíble concepción del basilisco ${ }^{70}$. Sólo el medioevo pudo escribir bestiarios moralizantes, que deleitaban con su fauna fascinante y dejaban, a la vez, una enseñanza provechosa para la vida.

\section{BIBLIOGRAFIA}

Fuentes manuscritas

DIGITAL BODLEIAN, Ms. Bodley 602 fol.34r [en línea] [consultado el 30 diciembre 2019].

Disponible en https://digital.bodleian.ox.ac.uk/inquire/p/72b4cc9e-128b-4969-

a39b-9d29875bc33b.

THE J. PAUL GETTY MUSEUM COLLECTION, Ms. Ludwig XV 3 (83.MR.173), fol. 83 [en línea] [consultado el 20 diciembre 2019]. Disponible en http://www.getty.edu/art/collection/objects/ 4806/unknown-maker-a-hunter-blowing-his-horn-and-a-beaver-franco-flemish-about-1270/? $\mathrm{dz}=0.5000,0.6130,0.92$.

THE MORGAN LIBRARY AND MUSEUM, Ms. M.459 fol. 7v [en línea] [consultado el 30 diciembre 2019]. Disponible en http://ica.themorgan.org/manuscript/page/14/145750.

WIKIMEDIA COMMONS CONTRIBUTORS, File: Matthew Paris Elephant from Parker MS 16 fol 151v.jpg [en línea]. Wikimedia Commons, the free media repository, 2018 [consultado el 31 diciembre 2019]. Disponible en https://commons.wikimedia.org/w/index.php? title=File:Matthew_Paris_Elephant_from_Parker_MS_16_fol_151v.jpg\&oldid=326905485. 
WIKIMEDIA COMMONS CONTRIBUTORS. File:83-Oxford Bodley 764- Elefante.jpg [en línea]. Wikimedia Commons, the free media repository, 2016 [consultado 31 diciembre 2019]. Disponible en https://commons.wikimedia.org/w/index.php?title=File:83-Oxford_Bodley_764-

_Elefante.jpg\&oldid=196331031.

WIKIMEDIA COMMONS CONTRIBUTORS. File: Sloane278 f.48v Elephants, Dragon, And Mandrake.jpg [en línea]. Wikimedia Commons, the free media repository, 2015 [consultado el 31 diciembre 2019]. Disponible en https://commons.wikimedia.org/w/index.php? title=File:Sloane278_f.48v_Elephants,Dragon,AndMandrake.jpg\&oldid=154968818.

Fuentes impresas

ARFE, Juan - Bestiario. Introducción Isabel Muñoz Jiménez. Madrid: Medusa, 2002.

ARISTÓTELES - Investigación sobre los animales. Introducción Carlos García Gual, traducción y notas Julio Pallí Bonet. Madrid: Gredos, 1992.

El Fisiólogo. Bestiario medieval. Ed. Nilda Guglielmi. Madrid: Eneida, 2002.

ELIANO, Claudio - Historia de los animales. Libros I-VIII. Ed. José María Díaz Regañón López. Madrid: Gredos, 1984.

FOURNIVAL, Richard - Bestiario de amor. Madrid: Miraguano, 1999.

GÓNGORA, Luis - Poesía: Soledades, Fábula de Polifemo y Galatea, Panegírico Al Duque de Lerma y Otros Poemas. Madrid: Taurus, 1981.

GRANADA, Luis de - Introducción del símbolo de la Fe (selección). in GAOS, José (selección, estudio preliminar y notas) - Escritores místicos españoles. Buenos Aires: Editorial Jackson, 1952.

LAGUNA Andrés - Bestiario de Dioscórides. Introducción y notas Carlos Ferrándiz Madrigal. Madrid: Medusa, 2001.

MALAXECHEVERRÍA, Ignacio - Bestiario medieval. Madrid: Siruela, 1999.

MŪSĀ B. ‘UBAID ALLĀH AL-QURTUBI AL-ISRĀ'ILI (Maimónides) - Maqala Tashtamil Ala Fusul Min Kitab Al-Hayawan Li-Aristu (Tract comprising Excerpts from Aristotles Book of Animals). Ed. y trad. John Nicholas Mattock en Arabics Technical and Scientific Texts. Vol. 2. Cambridge: Cambridge Middle East Centre, 1966.

NAUGHTON, Virginia (trad.) - Bestiario medieval. Buenos Aires: Quadrata, 2005

PLINIO SEGUNDO, Cayo - Historia natural. Libros II-IV. Coord. Ana María Moure Casas. Madrid: Gredos, 2003.

PLINIO SEGUNDO, Cayo - Historia natural. Libros VII-X. Coord. Ana María Moure Casas. Madrid: Gredos, 2003.

SAN ISIDORO DE SEVILLA - Etimologías. Eds. José Oroz Reta y Manuel Marcos Casquero. Madrid: Biblioteca de Autores Cristianos, 2004.

Estudios

AUERBACH, Erich - Figura. Madrid: Trotta, 1998.

CLARK, Willene B., MCMUNN, Meredith T (eds.) - Beasts and Birds of the Middle Ages: the bestiary and its legacy. Filadelfia: University of Pennsylvania, 1989.

DOCAMPO ÁLVAREZ, Pilar, MARTÍNEZ OSENDE, Javier, VILLAR VIDAL, José Antonio - "La versión C del Fisiólogo latino: el Codex bongarsianus 318 de Berna”. Medievalismo [en línea] 10 (2000), pp. 
27-67. [Consultado el 19 diciembre 2019]. Disponible en http://revistas.um.es/medievalismo/ article/view/51801.

ELIADE, Mircea - Imagen y símbolo. Madrid: Taurus, 1999.

ELIADE, Mircea - Tratado de Historia de las Religiones. Madrid: Ediciones Cristiandad, 2000.

FERRERO HERNÁNDEZ, Cándida - Liber contra venena et animalia venenosa. Estudio preliminar, edición crítica y traducción, (tesis doctoral). Barcelona: Universitat Autònoma de Barcelona, 2002. [consultado el 27 diciembre 2019]. Disponible en https://www.tdx.cat/handle/10803/5536.

GILSON, Étienne - La filosofía en la Edad Media. Madrid: Gredos, 1995.

GONZÁLEZ HERNANDO, Irene - "El fruto del deseo: connotaciones sexuales de la mandrágora desde Egipto hasta la Edad Media". Revista Digital de Iconografía Medieval [en línea] IX/17 (2017), pp. 61-79. [Consultado el 27 diciembre 2019]. Disponible en https://www.ucm.es/ bdiconografiamedieval/numero-17.

GONZÁLEZ HERNANDO, Irene; HERNÁNDEZ PÉREZ, Azucena - "Mandrágora”. in Base de datos digital de iconografía medieval [en línea]. Madrid: Universidad Complutense de Madrid, 2013. [consultado el 27 diciembre 2019]. Disponible en https://www.ucm.es/bdiconografiamedieval/ la-mandragora.

KUHRY, Emmanuelle - "Panorama des manuscrits et nouvelles ressources pour l'étude de la tradition manuscrite du Physiologus latin”. RursuSpicae [En línea] 2 (2019) [Consultado 20 de diciembre 2019]. Disponible en http://journals.openedition.org/rursuspicae/924.

LAUSBERG, Heinrich - Manual de retórica literaria. Madrid: Gredos, 1966.

LAZARIS, Stavros - Le Physiologus grec : la réécriture de l'histoire naturelle antique. Florencia: Sismel, 2016.

ORÍGENES - Comentario al Cantar de los Cantares. Trad. Argimiro Velasco. Madrid: Ciudad Nueva, 2007.

SAINTYVES, Pierre - L'astrologie populaire étudiée spécialement dans les doctrines et les traditions relatives à l'influence de la lune Essai sur la méthode dans l'étude du Folklore des opinions et des croyances. Librairie Emile Nourry: París, 1937.

UNIVERSITY OF CAMBRIDGE - Elephants and humans: a love affair over 1300 years [en línea] 2015. [Consultado el 20 diciembre 2019]. Disponible en https://www.cam.ac.uk/research/features/ elephants-and-humans-a-love-affair-over-1300-years.

VARVARO, Alberto - Literatura románica de la Edad Media. Barcelona: Ariel, 1983.

ZAMBÓN, Francesco - El alfabeto simbólico de los animales. Los bestiarios de la Edad Media. Madrid: Siruela, 2010.

\section{NOTAS}

1. I, Cor 1, 20-27.

2. VARVARO, Alberto - Literatura románica de la Edad Media. Barcelona: Ariel, 1983, p. 43.

3. Para referirse a la profecía real, en latín, además de figura, aparecen expresiones derivadas del griego como allegoria y typus. Tertuliano utiliza a veces allegoria como sinónimo de figura. Sin embargo, la allegoria, si bien señala también un significado profundo, se extiende más allá de la profecía real. La figura, que sí correspondía a la profecía real, abarcaba toda la noción de formación o configuración, plasmada en el desarrollo del concepto desde los retóricos paganos 
hasta los Padres de la Iglesia, al contrario de typo, que si bien era una expresión equivalente, al ser un extranjerismo carecía de la carga semántico-histórica de palabra figura (AUERBACH, Erich - Figura. Madrid: Trotta, 1998, pp. 91-92).

4. LAUSBERG, Heinrich - Manual de retórica literaria. Madrid: Gredos, 1966, pp. 288-290. Citado por VARVARO - Literatura románica ..., p. 51.

5. Es preciso aclarar, no obstante, que el hecho de ser realidades concretas refería a su existencia en tanto género, no a una ubicación espaciotemporal determinada, con lo cual no es posible hablar aquí de interpretación figural, que se aplica, como dijimos, a acontecimientos históricos. Disentimos con Várvaro, quien considera que los bestiarios representan una extensión del procedimiento tipológico "de la historia y del tiempo a la naturaleza y lo permanente" (VARVARO - Literatura románica ..., p. 53), lo que entra en contradicción con la definición de Lausberg, mencionada anteriormente, que él mismo cita para aclarar la diferencia entre tipología y alegoría.

6. KUHRY, Emmanuelle - "Panorama des manuscrits et nouvelles ressources pour l'étude de la tradition manuscrite du Physiologus latin”. RursuSpicae [En línea] 2 (2019). [Consultado el 27 diciembre 2019]. Disponible en http://journals.openedition.org/rursuspicae/924, p. 2.

7. CLARK, Willene B.; McMUNN, Meredith T. (eds.) - Beasts and Birds of the Middle Ages: the bestiary and its legacy. Filadelfia: University of Pennsylvania, 1989, introducción, p. 3.

8. El origen alejandrino estaría avalado por la mención de animales de la fauna egipcia, como por ejemplo, el cocodrilo, la mangosta, el ibis, el mono (El Fisiólogo. Bestiario medieval. Ed. Nilda Guglielmi. Madrid: Eneida, 2002, pp. 41-42). Stavros Lazaris, en un estudio reciente sostiene, igualmente, que el anónimo autor del Fisiólogo griego lo escribió en Alejandría en el siglo II (LAZARIS, Stavros - Le Physiologus grec: la réécriture de l'histoire naturelle Antique. Florencia: Sismel, 2016, pp. 9-31).

9. El Fisiólogo. Bestiario medieval ..., p. 40.

10. En el estudio introductorio a la Historia de los animales, Díaz Regañón López afirma que “(...) prescindiendo de valores intrínsecos que pueda tener la obra de Eliano, el principal interés que ofrece es el de presentarnos el pensamiento de muchos autores, cuyas obras podemos considerar definitivamente perdidas" (ELIANO, Claudio - Historia de los animales. Libros I-VIII. Ed. José María Díaz Regañón López. Madrid: Gredos, 1984, p. 15).

11. El Fisiólogo. Bestiario medieval ..., p. 11.

12. "Cabe pensar, fundadamente, que son todos de origen bíblico; figuran en la Vulgata todos menos diez: castor, phoenix, panthera, serra, hyaena, hydrus, ichneumon, enudris, autolops y mirmicoleon. De estos, hydrus, enudris e ichneumon son, en opinión de F. McCulloch el mismo animal. Además, en la versión bíblica de los LXX aparecen panthera, hyaena, y mirmicoleon (los dos primeros también aparecen en alguna versión de la ítala)" (DOCAMPO ÁLVAREZ, Pilar, MARTÍNEZ OSENDE, Javier, VILLAR VIDAL, José Antonio - "La versión C del Fisiólogo latino: el Codex bongarsianus 318 de Berna". Medievalismo [en línea] 10 (2000), pp. 27-67 [Consultado el 19 diciembre 2019]. Disponible en http://revistas.um.es/medievalismo/article/view/51801, p. 29.

13. No siempre es fantástica: muchos datos son ciertos, como el tiempo de gestación del elefante, dos años, tal como se afirma en el bestiario latino de Cambridge (MALAXECHEVERRÍA, Ignacio Bestiario medieval. Madrid: Siruela, 1999, p. 73).

14. CLARK, Willene B.; McMUNN, Meredith T. (eds.) - Beasts and Birds of the Middle Ages ..., pp. 2-3.

15. CLARK, Willene B.; McMUNN, Meredith T. (eds.) - Beasts and Birds of the Middle Ages ..., p. 3.

16. El Fisiólogo. Bestiario medieval ..., pp. 45-46.

17. El Fisiólogo. Bestiario medieval ..., p .108.

18. Se lo consideraba un eficaz antídoto del veneno de las serpientes, y un buen remedio para el hipo, la flatulencia y las enfermedades de los nervios. No debe confundirse con el aceite de castor, nombre común del aceite de ricino. 
19. MALAXECHEVERRÍA, Ignacio - Bestiario medieval ..., p. 85.

20. El Fisiólogo. Bestiario medieval ..., p. 106.

21. MALAXECHEVERRÍA, Ignacio - Bestiario medieval ..., p. 210.

22. Según el bestiario latino de Cambridge, San Agustín y Santo Tomás Becket refieren la fecundación de la Virgen por el oído mediante la palabra de Dios llevada por el ángel (MALAXECHEVERRÍA, Ignacio - Bestiario medieval ..., p. 212).

23. MALAXECHEVERRÍA, Ignacio - Bestiario medieval ..., pp. 211-212.

24. ELIADE, Mircea - Imagen y símbolo. Madrid: Taurus, 1999, p. 137.

25. SAINTYVES, Pierre. - L'Astrologie populaire, étudiée spécialement dans les doctrines et les traditions relatives à l'influence de la lune. Paris: Librairie Emile Nourry, 1937, p. 231 y siguiente. Citado por ELIADE, Mircea - Imagen y símbolo ..., p. 139.

26. ELIADE, Mircea - Imagen y símbolo ..., p. 156.

27. El Fisiólogo. Bestiario medieval ..., p. 93.

28. MALAXECHEVERRÍA, Ignacio - Bestiario medieval ..., p. 124.

29. MALAXECHEVERRÍA, Ignacio - Bestiario medieval ..., pp. 124-125.

30. El Fisiólogo. Bestiario medieval ..., pp. 89-90.

31. "El dragón es la mayor de las serpientes", según el bestiario de Cambridge o bien, es una serpiente que con el transcurso del tiempo y el consiguiente aumento de tamaño, se vuelve dragón, según el Nuzhatu-l-Qulūb, enciclopedia persa del siglo XIII (citados ambos en MALAXECHEVERRÍA, Ignacio - Bestiario medieval ..., pp. 223-224).

32. "Científico" en el sentido en que se lo consideraba en el medioevo: un conocimiento no basado en la observación directa y en la experimentación, sino en la autoridad de las fuentes, y fundamentalmente, a pesar del soporte escrito, en el hecho de ser en su origen, un testimonio oral. Sería un error denominar a los bestiarios "pseudocientíficos", como lo hace Nilda Gugliemi en su edición crítica de El Fisiólogo, por el hecho de que a nosotros, lectores inmersos en la concepción moderna de la ciencia, nos resulten fantásticos e increíbles.

33. ELIANO, Claudio - Historia de los animales ..., pp. 357-358.

34. PLINIO SEGUNDO, Cayo - Historia natural. Libros VII-XI. Coord. Ana María Moure Casas. Madrid: Gredos, 2003, p. 122.

35. ARISTÓTELES - Investigación sobre los animales. Introducción Carlos García Gual, traducción y notas Julio Pallí Bonet. Madrid: Gredos, 1992, p. 242.

36. Según la Flore populair de Rolland, citado en nota 387 de la edición crítica de Cándida Ferrero Hernández del Liber contra venena, de Juan Gil de Zamora (FERRERO HERNÁNDEZ, Cándida - Liber contra venena et animalia venenosa. Estudio preliminar, edición crítica y traducción. Barcelona: Universitat Autònoma de Barcelona, 2002. Tesis Doctoral. [consultado el 27 diciembre 2019]. Disponible en https://www.tdx.cat/handle/10803/5536. En el libro del Génesis también se mencionar el poder fecundador de las mandrágoras, que la infértil Raquel pide a su hermana Lía para poder concebir un hijo de Jacob (Gn., 30, 14). En cuanto a sus propiedades afrodisíacas, ya eran conocidas en el Antiguo Egipto, y su fruto aparece en diferentes representaciones como símbolo de fertilidad (GONZÁLEZ HERNANDO, Irene - "El fruto del deseo: connotaciones sexuales de la mandrágora desde Egipto hasta la Edad Media". Revista Digital de Iconografía Medieval IX/17 (2017), pp. 61-79 [Consultado 27 diciembre 2019]. Disponible en https://www.ucm.es/ bdiconografiamedieval/numero-17, pp. 63-65). El nombre científico es Mandrágora officinalis y es una solanácea similar en sus efectos a la belladona. Sus virtudes mágicas eran atribuidas a que la raíz tenía forma humana (un metro a de largo, aproximadamente, terminada en dos 'patas'): aquel que intentara arrancarla, perecía, por eso se utilizaba un perro para la extracción, el cual se ataba a la planta y se le hacía tirar de ella.

37. Este bestiario propone una interesante variación: es el macho quien come primero y luego le ofrece a su compañera. En la interpretación alegórica, se aclara específicamente que la 
mandrágora es el Árbol de la Ciencia, y es la mujer quien prueba primero el fruto (MALAXECHEVERRÍA, Ignacio - Bestiario medieval ..., p. 73).

38. El Papiro de Tebtunis, hallado en Egipto, pero escrito en griego, del siglo II d.C. es un fragmento de un texto médico sobre las propiedades de las plantas; cabría suponer que podría haber estado incluida la mandrágora (GONZÁLEZ HERNANDO, Irene - "El fruto del deseo: connotaciones sexuales de la mandrágora desde Egipto hasta la Edad Media" ..., p. 68). Este, u otros textos similares podrían haber estado al alcance del autor del Fisiólogo alejandrino.

39. El Fisiólogo. Bestiario medieval ..., p. 151, nota 113.

40. SAN ISIDORO DE SEVILLA - Etimologías. Eds. José Oroz Reta y Manuel Marcos Casquero. Madrid: Biblioteca de Autores Cristianos, 2004, p. 905.

Según De las propiotas de las animanças, bestiario valdense cuyo arquetipo desconocido probablemente date del siglo XIII, el parto se realiza en el agua porque en tierra el pequeño elefante no podría pararse, o ser levantado (MALAXECHEVERRÍA, Ignacio - Bestiario medieval ..., p. 76). Se advierte aquí un eco del difundido error de la ausencia de rodillas.

41. Esta misma especie es recogida en un manuscrito tardomedieval, Proprietez des bestes, en aproximadamente los mismos términos, sólo que es un dragón en vez de una serpiente (MALAXECHEVERRÍA, Ignacio - Bestiario medieval ..., p. 77).

42. Algún viso de realidad tiene este hecho, ya que las orejas están muy vascularizadas para perder calor.

43. Así lo sostiene Nilda Guglielmi en su edición de El Fisiólogo (p. 94, nota 113).

44. ELIADE, Mircea - Tratado de Historia de las Religiones. Madrid: Ediciones Cristiandad, 2000, pp. 304 y ss.

45. El Fisiólogo. Bestiario medieval ..., p. 94, nota 113.

46. Como no puede flexionar sus patas, no puede acostarse, y debe, entonces, dormir de pie. Véase MALAXECHEVERRÍA, Ignacio - Bestiario medieval ..., p. 74.

47. ELIANO, Claudio - Historia de los animales ..., p. 163.

48. ELIANO, Claudio - Historia de los animales ..., p. 167.

49. PLINIO SEGUNDO, Cayo - Historia natural ..., p. 127.

50. ELIANO, Claudio - Historia de los animales ..., pp. 129-130.

51. NAUGHTON, Virginia (trad.) - Bestiario medieval. Buenos Aires: Quadrata, 2005, p. 63; sigue la edición crítica de T.H.White, The Bestiary: A Book of Beasts, de 1954.

52. Naturalmente, estaba lejos del pensamiento medieval cuestionarse cómo un pequeño era capaz de levantar a tantos elefantes más grandes que él. Bastaba con que tuviera la significación moral que se le asignaba para que fuera verdadero.

53. MŪSĀ B. 'UBAID ALLĀH AL-QURTUBI AL-ISRĀ'ILI (Maimónides) - Maqala Tashtamil Ala Fusul Min Kitab Al-Hayawan Li-Aristu (Tract comprising Excerpts from Aristotles Book of Animals). Ed. y trad. John Nicholas Mattock en Arabics Technical and Scientific Texts, vol. 2. Cambridge: Cambridge Middle East Centre, 1966.

54. ARISTÓTELES - Investigación sobre los animales ..., p. 85.

55. MŪSĀ B. 'UBAID ALLĀH AL-QURTUBI AL-ISRĀ'ILI - Maqala, introducción, pp. viii-ix.

56. La figura 6 es el dibujo que Mateo de París, un monje benedictino y cronista oficial de St. Albans, hizo del elefante de Federico II que este enviara a recibir a su cuñado Ricardo de Cornualles en Cremona, sin tener conocimiento directo del animal. Cuando vio en Londres el elefante africano que le regalara Luis IX a Enrique III, dibujó lo que es la más temprana representación realista occidental de un elefante, con articulaciones en las patas y las proporciones adecuadas. Ambas ilustracines aparecen en Chronica Maiora, una historia del mundo compilada por él. Para ver imagen y acceder a más información sobre ella: UNIVERSITY OF CAMBRIDGE - Elephants and humans: a love affair over 1300 years [en línea], 2015 [Consultado el 20 diciembre 2019]. Disponible en https://www.cam.ac.uk/research/features/elephants-andhumans-a-love-affair-over-1300-years. 
57. ELIANO, Claudio - Historia de los animales ..., p.94.

58. "Orígenes concluye que en la naturaleza, lo mismo que en las escrituras, 'se puede relacionar el ámbito de lo visible con el de lo invisible, lo que está manifiesto con lo que está oculto, lo corpóreo con lo incorpóreo, y se puede pensar que la sabiduría divina creó el mundo de tal manera que gracias a las mismas cosas que sirven de ejemplo (rebus ipsis et exemplis) aquel nos instruye sobre las realidades invisibles a partir de las visibles, y nos traslada desde las realidades terrenales hasta las realidades celestiales" (ZAMBóN, Francesco - El alfabeto simbólico de los animales. Los bestiarios de la Edad Media. Madrid: Siruela, 2010, p. 30). Se cita a Orígenes según la traducción de Argimiro Velasco (ORÍGENES - Comentario al Cantar de los Cantares. Trad. Argimiro Velasco. Madrid: Ciudad Nueva, 2007, pp. 211-212).

59. En las creaturas los tres aspectos, que corresponden al Padre, Hijo y SS, son modus, species, ordo (o también mensura, numerus, pondus) respectivamente; en el hombre, memoria, ratio, voluntas.

60. ZAMBÓN, Francesco - El alfabeto simbólico de los animales ..., p. 37.

61. Un ejemplo de este espíritu racionalista y experimental es la crítica que hace Alberto Magno a varias de las leyendas popularizadas por el Fisiólogo en su obra De animalibus, por ejemplo, aquella que relata que el avestruz se alimenta de hierro, y que el autor refuta tras habérselos ofrecido, sin éxito (ZAMBÓN, Francesco - El alfabeto simbólico de los animales ..., p. 44).

62. Para un panorama más amplio del platonismo y aristotelismo medievales, véase GILSON, Étienne - La filosofía en la Edad Media. Madrid: Gredos, 1995.

63. FOURNIVAL, Richard - Bestiario de amor. Madrid: Miraguano, 1999, pp. 62-63.

64. FOURNIVAL, Richard - Bestiario de amor ..., p. 33.

65. LAGUNA Andrés - Bestiario de Dioscórides. Introducción y notas Carlos Ferrándiz Madrigal. Madrid: Medusa, 2001, p. 123.

66. ARFE, Juan - Bestiario. Introducción Isabel Muñoz Jiménez. Madrid: Medusa, 2002, p. 31.

67. GRANADA, Luis de - Introducción del símbolo de la Fe (selección). in GAOS, José (selección, estudio preliminar y notas) - Escritores místicos españoles. Buenos Aires: Editorial Jackson, 1952, p. 67.

68. GÓNGORA, Luis - Poesía: Soledades, Fábula de Polifemo y Galatea, Panegírico Al Duque de Lerma y Otros Poemas. Madrid: Taurus, p. 140.

69. Producto de la cruza de un león con una hormiga. Su parte delantera era de león y la trasera de hormiga.

70. Nace del huevo puesto por un gallo (no una gallina) e incubado por un sapo.

\section{RESUMOS}

Gran parte de la historia del pensamiento medieval estuvo bajo la influencia del platonismo y las reelaboraciones que de las doctrinas de Platón hicieron los Padres latinos y griegos. La cosmovisión resultante de este pensamiento consideraba que cada manifestación del mundo sensible, en tanto participaba de la naturaleza de Dios, era la oportunidad de acceder a un saber trascendente. Entre estas manifestaciones, tuvieron un papel destacado los animales. Los saberes zoológicos heredados de la antigüedad clásica fueron resignificados y enriquecidos a través de una exégesis que transformó a las bestias en ejemplos que ilustraban aspectos de la doctrina cristiana o suministraban modelos de conducta moral. El Fisiólogo y sus derivados, los bestiarios medievales, son ejemplo de esta práctica interpretativa, que para estos textos se basó 
fundamentalmente en la alegoría. En este artículo, nos proponemos ver de qué manera y con qué objetivos se aplicó a los animales e indagaremos sobre la evolución del simbolismo animal en el marco de la decadencia del platonismo y el auge del aristotelismo en los últimos siglos de la Edad Media. Para esto, nos detendremos en el análisis de un breve corpus, compuesto por el castor, la comadreja, la ostra y la perla, y el elefante.

Most of the history of medieval thought was influenced by Platonism and the reworkings that the Latin and Greek Fathers made of Plato's doctrines. The worldview resulting from this thought considered that each manifestation of the sensible world, while participating in the nature of God, was the opportunity to access transcendent knowledge. Among these manifestations, animals played a prominent role. Zoological knowledge inherited from classical antiquity was given new meaning and enriched through an exegesis that transformed beasts into examples that illustrated aspects of Christian doctrine or provided models of moral conduct. The Physiologus and its derivatives, the medieval bestiaries are an example of this interpretive practice, which for these texts was based primarily on allegory. In this article, we propose to see how and with what objectives it was applied to animals and we will inquire about the evolution of animal symbolism in the framework of the decline of Platonism and the rise of Aristotelianism in the last centuries of the Middle Ages. For this, we will analyze a brief corpus, composed of the beaver, the weasel, the oyster and the pearl, and the elephant.

\section{ÍNDICE}

Keywords: Allegory, Bestiary, Platonism, Aristotelianism, Middle Ages

Palabras claves: Alegoría, Bestiario, Platonismo, Aristotelismo, Edad Media

\section{AUTOR}

\section{CLAUDIA INÉS RAPOSO}

Universidad de Buenos Aires, Facultad de Filosofía y Letras, Instituto de Filología y Literatura Hispánicas “Dr. Amado Alonso”. C.P. 1714, Ituzaingó, Buenos Aires, Argentina.

claudiaraposo61@gmail.com .https://orcid.org/0000-0001-7768-7881 